\title{
$\beta$-Adrenoceptor activation enhances L-type calcium channel currents in anterior piriform cortex pyramidal cells of neonatal mice: implication for odor learning
}

\author{
Abhinaba Ghosh, Bandhan Mukherjee, Xihua Chen, and Qi Yuan \\ Biomedical Sciences, Faculty of Medicine, Memorial University of Newfoundland, St. John's, Newfoundland and Labrador A1B 3V6, \\ Canada
}

\begin{abstract}
Early odor preference learning occurs in one-week-old rodents when a novel odor is paired with a tactile stimulation mimicking maternal care. $\beta$-Adrenoceptors and L-type calcium channels (LTCCs) in the anterior piriform cortex (aPC) are critically involved in this learning. However, whether $\beta$-adrenoceptors interact directly with LTCCs in aPC pyramidal cells is unknown. Here we show that pyramidal cells expressed significant LTCC currents that declined with age. $\beta$-Adrenoceptor activation via isoproterenol age-dependently enhanced LTCC currents. Nifedipine-sensitive, isoproterenol enhancement of calcium currents was only observed in post-natal day 7-10 mice. APC $\beta$-adrenoceptor activation induced early odor preference learning was blocked by nifedipine coinfusion.
\end{abstract}

L-type calcium channels (LTCCs) are expressed in the heart (Hess et al. 1986) and brain (Hell et al. 1993). In neurons, LTCC-mediated calcium influx is critical for long-term potentiation (Grover and Teyler 1990; Kapur et al. 1998; Weisskopf et al. 1999; Moosmang et al. 2005), the putative cellular mechanism for learning. Blockade of LTCC leads to deficits in different learning paradigms including passive avoidance learning (Lashgari et al. 2006), spatial memory (Moosmang et al. 2005), fear extinction (Davis and Bauer 2012), and olfactory associative learning (Zhang et al. 2010; Jerome et al. 2012). Up-regulation of LTCC Cav1.2 subunit activity by $\beta$-adrenoceptor signaling plays an important role in regulating $\mathrm{Ca}^{2+}$ influx into myocytes (Reuter 1983; Yue et al. 1990) and neurons (Gray and Johnston 1987; Kavalali et al. 1997; Hoogland and Saggau 2004). However, few studies have looked at the functional role of $\beta$-adrenoceptor modulation of LTCCs in learning.

Early odor preference learning is a type of classical conditioning in which a tactile stimulus mimicking maternal care (e.g., brush stroking) serves as the unconditioned stimulus (US), and a novel odor serves as the conditioned stimulus (CS). The pairing of the US and CS lead to an approach response to the CS odor, lasting hours to days depending on the training paradigms (Yuan et al. 2014). Tactile stimulation triggers norepinephrine release onto the olfactory bulb and anterior piriform cortex (aPC) and activates the cAMP/PKA pathway via $\beta$-adrenoceptors (McLean et al. 1999; Grimes et al. 2012; Morrison et al. 2013; Ghosh et al. 2015). Early odor preference learning occurs in a sensitive post-natal period and terminates around post-natal day (PD) 10 (Sullivan et al. 2000) when a tactile stimulus no longer triggers sufficient norepinephrine release (Nakamura et al. 1987). NMDA receptors (NMDARs) and LTCCs activated upon exposure to an odor critically mediate calcium-dependent kinase activities (Jerome et al. 2012; Lethbridge et al. 2012; Morrison et al. 2013). The convergence of the US and CS pathways leads to CREB phosphorylation and CREB-dependent transcription critical for odor learning (McLean et al. 1999; Yuan et al. 2003, 2014). Here we investigated whether $\beta$-adrenoceptors directly modulate LTCCs in aPC pyrami-

Corresponding authors: qi.yuan@med.mun.ca; xihuac@mun.ca Article is online at http://www.learnmem.org/cgi/doi/10.1101/lm.044818.116. dal cells as seen in heart (Yue et al. 1990) and hippocampal neurons (Gray and Johnston 1987; Kavalali et al. 1997; Hoogland and Saggau 2004). We compared the proportions of the LTCC currents and $\beta$-adrenoceptor modulations in pups within and beyond the sensitive period. The interaction of $\beta$-adrenoceptors and LTCCs in early odor preference learning was studied with pharmacological manipulations in the aPC during training.

All experimental procedures were approved by the Animal Care Committee at Memorial University and adhered to Canadian Council on Animal Care guidelines. C57B1/6J mice (Charles River) were bred on site. Dams were maintained under a 12-h light-dark cycle with ad libitum food and water. Day of birth was considered PDO.

We used whole-cell patch clamp recording to study aPC pyramidal cell calcium currents. Mouse pups of either sex from P7-10 and P14 above (P14-20) age groups were anesthetized with isoflurane and decapitated. Brains were extracted quickly and put in ice cold high-sucrose solution containing (in $\mathrm{mM}$ ): $83 \mathrm{NaCl}$, $2.5 \mathrm{KCl}, 3.3 \mathrm{MgSO}_{4}, 1 \mathrm{NaH}_{2} \mathrm{PO}_{4}, 26.2 \mathrm{NaHCO}_{3}, 22$ glucose, 72 sucrose, $0.5 \mathrm{CaCl}_{2}$, bubbled with $95 \% \mathrm{O}_{2}$ and $5 \% \mathrm{CO}_{2}$. Para-sagittal slices of $300 \mu \mathrm{m}$ thickness were cut in Leica vibratome (VT 1000P) and incubated in sucrose solution at $35^{\circ} \mathrm{C}$ for $30 \mathrm{~min}$ and then left at room temperature. Slices were transferred to a recording chamber perfused with warm $\left(30^{\circ} \mathrm{C}-32^{\circ} \mathrm{C}\right)$ Barium artificial CSF (aCSF) containing (in $\mathrm{mM}$ ): $110 \mathrm{NaCl}, 2.5 \mathrm{KCl}, 1.3$ $\mathrm{MgCl}_{2}, 1 \mathrm{NaH}_{2} \mathrm{PO}_{4}, 26.2 \mathrm{NaHCO}_{3}, 22$ glucose, $2.5 \mathrm{BaCl}_{2}$, tetrodotoxin $(0.5 \mu \mathrm{M}$; Tocris) with a flow rate of $2-3 \mathrm{~mL} / \mathrm{min}$. Slices were viewed with Olympus BX51WI upright microscope in differential interference contrast. Whole-cell $\mathrm{Ca}^{2+}$ currents were recorded selectively from layer II pyramidal neurons with 3-6 M $\Omega$ glass micropipette pulled in a Flaming/Brown puller (P-97, Stutter Instrument Co.). To distinguish from semilunar cells, pyramidal cells were selected by somatic morphology under DIC (oval shaped vs. semilunar shaped), depth in the layer II (deeper vs.

\footnotetext{
C 2017 Ghosh et al. This article is distributed exclusively by Cold Spring Harbor Laboratory Press for the first 12 months after the full-issue publication date (see http://learnmem.cshlp.org/site/misc/terms.xhtml). After 12 months, it is available under a Creative Commons License (AttributionNonCommercial 4.0 International), as described at http://creativecommons. org/licenses/by-nc/4.0/.
} 
superficial) (Suzuki and Bekkers 2011). In a previous report (Ghosh et al. 2015), we used the same criterion of cell selection and posthoc biocytin reconstruction demonstrated that the majority of cells recorded were pyramidal cells. Intrapipette solution contained (in mM): 130 D-gluconic acid, $130 \mathrm{CsOH}, 5 \mathrm{NaCl}, 10$ HEPES, 12 phosphocreatine, 3 MgATP, 0.2 NaGTP, and 0.2 EGTA. Cells included in the data set had an initial access resistance $<20 \mathrm{M} \Omega$ with $<25 \%$ change throughout the duration of recording.

Cells were held at $-70 \mathrm{mV}$ in voltage-clamp mode, and depolarizing currents were injected into the cell through a recording pipette for $150 \mathrm{msec}$ during each step. Steps ranged from -60 to $10 \mathrm{mV}$ with $5 \mathrm{mV}$ increase in each step. It is been reported that nifedipine-sensitive LTCCs in the piriform cortex demonstrates slow kinetics and half activation $\sim 0 \mathrm{mV}$ (Magistretti et al. 1999). $\mathrm{Ca}^{2+}$ current was measured during the $0 \mathrm{mV}$ step at its steady state at $146 \mathrm{msec}$. Control traces were recorded $10 \mathrm{~min}$ after establishing the whole-cell configuration. Drugs (LTCC antagonist nifedipine, $10 \mu \mathrm{M}$; $\beta$-adrenoceptor agonist isoproterenol, $10 \mu \mathrm{M}$; PKA inhibitor H89, $10 \mu \mathrm{M}$; Sigma) were added to the aCSF for $10 \mathrm{~min}$ and then washed with aCSF for $30 \mathrm{~min}$. Cadmium chloride (100 $\mu \mathrm{M}$, Sigma) was added to the bath at the end of the experiments. Leak subtraction was done by subtracting cadmium traces from corresponding control, drug, and wash traces as shown in example traces. Multiclamp 700B amplifier and pClamp10 software was used for data acquisition. Signals were filtered at $2 \mathrm{kHz}$ and digitized at $10 \mathrm{kHz}$ sampling frequency. Clampfit 10.6 was used for data analysis.

Figure 1 shows the whole-cell calcium currents and nifedipine-sensitive LTCCs in two age groups (P7-10 vs. $>$ P14). Whole-cell $\mathrm{Ca}^{2+}$ currents were reduced in the presence of nifedipine, suggesting an LTCC-mediated component. The LTCC component was significantly bigger in P7 -10 pups $(49.5 \% \pm 4.09 \%$ of the control, $n=11$, example current traces in one animal are shown in Figure 1A upper panel and the $I-V$ curve is shown in the lower panel) than in P14 above pups $(27.2 \% \pm 6.05 \%, n=8$, $t=3.18, P=0.006$; examples are shown in Fig. $1 \mathrm{~B}$; the comparison of the two age groups is shown in Fig. 1C). The larger portion
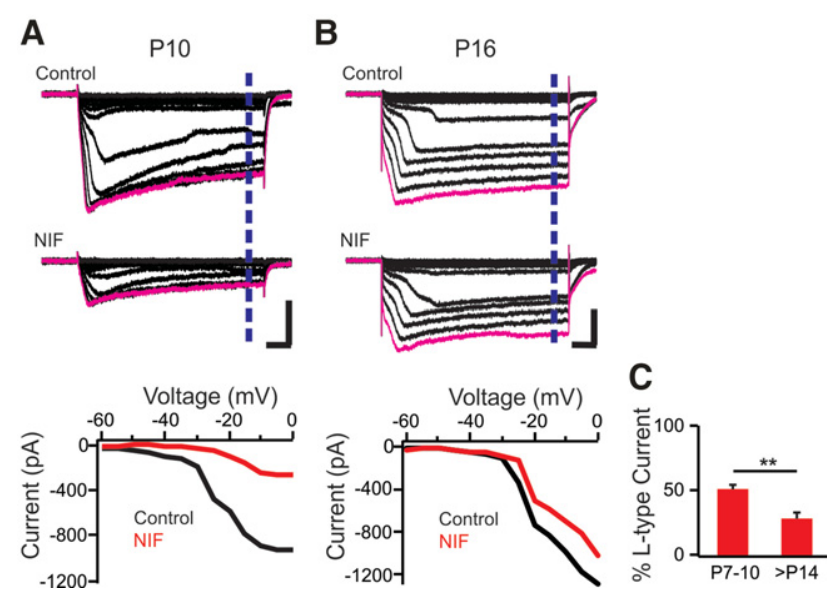

Figure 1. L-type calcium currents (LTCCs) in mouse pups of P7-11 and P14 above. $(A)$ Example traces of whole-cell currents in a P10 mouse pup under control condition and during nifedipine (NIF) application (upper panel) and $I-V$ relationship (lower panel). (B) Example traces of whole-cell currents in a P16 mouse pup under control condition and during nifedipine (NIF) application (upper panel) and $I-V$ relationship (lower panel). Scale bars: $25 \mathrm{msec}$ and $500 \mathrm{pA}$. Dotted lines indicate the time point for calcium current measurement. (C) Percentage of LTCC currents in P7-11 and P14 above mice. $\left({ }^{*}\right) P<0.05$. of the LTCC current in P7-10 pups correlates with a highly plastic period in which LTCC-dependent early odor preference learning occurs (Jerome et al. 2012; Mukherjee and Yuan, 2016).

Figure $2 \mathrm{~A}$ and $\mathrm{B}$ demonstrated effects of isoproterenol on the whole-cell calcium currents in the two age groups. $\beta$ Adrenoceptor activation by isoproterenol moderately increased whole-cell $\mathrm{Ca}^{2+}$ current in P7-10 mice $(115 \% \pm 7 \%$ normalized to the control, compared with the wash $101 \% \pm 3 \%, n=8, t=$ 2.51, $P=0.04$, paired $t$-test; Fig. 2A). However, isoproterenol was ineffective in older pups $(96 \% \pm 5 \%$ normalized to the control, compared with the wash $94 \% \pm 6 \%, n=7, t=0.44, P=0.68$, paired $t$-test; Fig. 2B). In subsequent experiments, we tested whether isoproterenol enhanced LTCCs in the younger age group. Nifedipine application prior to isoproterenol abolished the effect of isoproterenol on whole-cell $\mathrm{Ca}^{2+}$ currents in P7-10 pups (normalized to control, nifedipine: $52 \% \pm 6 \%$, nifedipine + isoproterenol: $53 \% \pm 4 \%, n=5, t=0.23, P=0.83$, paired $t$-test; Fig. $2 \mathrm{C}$ ). This result suggests that $\beta$-adrenoceptor activation enhances LTCC-mediated currents in young pups during the sensitive period. Finally, isoproterenol enhancement of whole-cell $\mathrm{Ca}^{2+}$ current was also dependent on the cAMP/PKA activation. PKA inhibitor H89 preincubation prevented isoproterenol mediated increase in $\mathrm{Ca}^{2+}$ currents (normalized to the control: $96 \% \pm 3 \%$ in $\mathrm{H} 89,91 \% \pm 5 \%$ in isoproterenol, $n=5, t=1.34, P=0.25$, paired $t$-test; Fig. 2D).

We then investigated interaction of the $\beta$-adrenoceptors and LTCCs in learning during the sensitive period. Behavioral study was done at $27^{\circ} \mathrm{C}$ with previously established protocols (Morrison et al. 2013; Ghosh et al. 2015). Briefly, intracranial infusion surgery and odor training were carried out on P7 pups. Pups were anesthetized via hypothermia (under ice) and placed in a stereotaxic apparatus. After an incision of the skin, two small holes were drilled. Of note, $0.5 \mu \mathrm{L}$ of drug (isoproterenol 500 $\mu \mathrm{M}$, dissolved in saline; nifedipine $100 \mu \mathrm{M}$ dissolved in $1 \%$ ethanol + saline; isoproterenol + nifedipine; isoproterenol + H89 $100 \mu \mathrm{M}$ dissolved in saline; isoproterenol + APV $100 \mu \mathrm{M}$ dissolved in saline) or vehicle ( $1 \%$ ethanol + saline) was infused bilaterally in specific coordinates for aPC (1.8 $\mathrm{mm}$ anterior and 2 $\mathrm{mm}$ bilateral, $3.5 \mathrm{~mm}$ ventral with respect to the bregma) at the rate of $0.25 \mu \mathrm{L} / \mathrm{min}$ through cannulas attached to the infusion tubing. The infusion tubing was attached to a Hamilton syringe driven by a precision pump (Fusion 400, Chemyx Inc.). One minute after infusion, cannulas were gently withdrawn, skin was sutured, and pups were left for 30 min on warm bedding for recovery before odor training.

Pups were placed on peppermint-scented bedding $(0.3 \mathrm{~mL}$ peppermint extract in $500 \mathrm{~mL}$ bedding) for $10 \mathrm{~min}$ and were returned to the dam afterward. Twenty-four hours after the training, pups were placed in a two-choice testing apparatus consisting of a stainless steel box $(30 \times 20 \times 18 \mathrm{~cm})$ with mesh bottom kept over two training boxes-one with peppermint-scented bedding and the other with non-scented normal bedding. Time spent over either side was recorded in five 1-min trials with 1 min rest in between trials. Time spent over peppermint bedding was measured as percentage of total trial time. The aPC location was verified with methylene blue ( $2 \%)$ in the pilot experiments $(n=6)$, and infusion tracks were checked in pups following testing.

Previous research has shown that aPC adrenoceptors are critical for early odor preference learning in rodents (Morrison et al. 2013; Ghosh et al. 2015). Blocking $\beta$-adrenoceptors with propranolol systemic injection prevented odor preference learning in mice induced by pairing peppermint odor with stroking (Ghosh et al. 2015). In Figure 3, we show different behavioral outputs (percentage of time spent over peppermint-scented bedding during the testing) in pups with aPC drug or vehicle infusions. Training and testing schematic is shown in the upper panel of Figure 
A

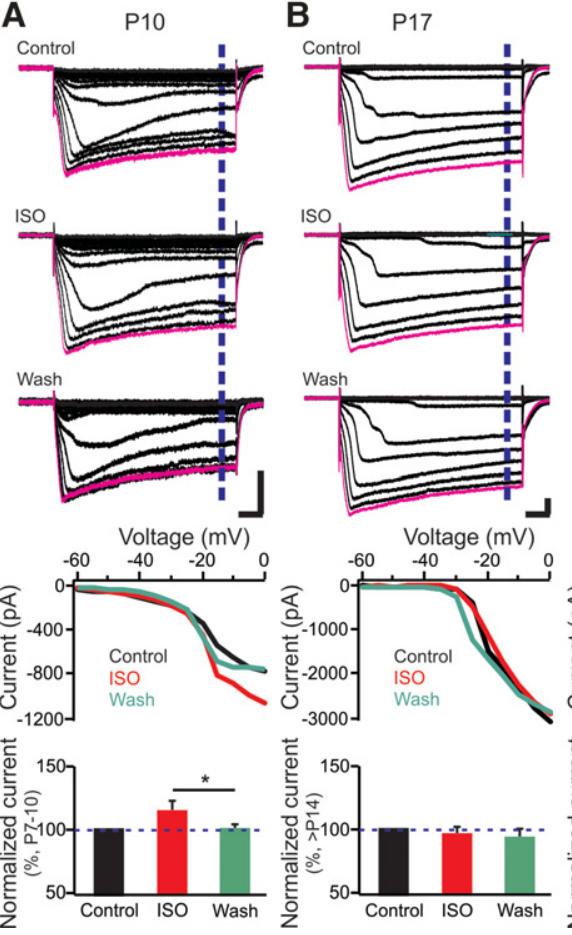

C

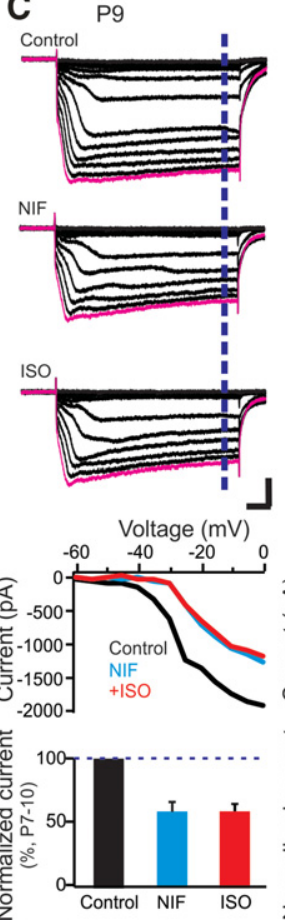

D

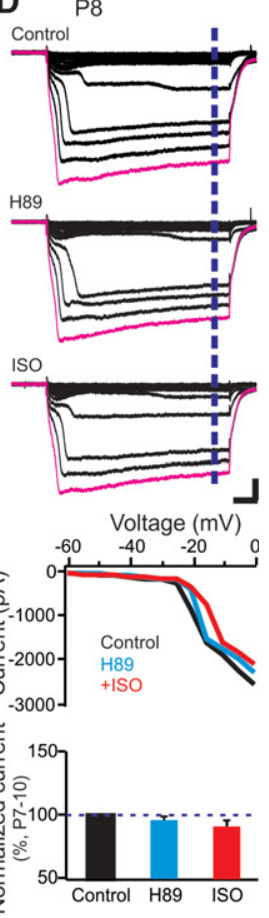

Figure 2. Effects of $\beta$-adrenoceptor activation on whole-cell $\mathrm{Ca}^{2+}$ currents. (A) Example traces of whole-cell currents in a P10 mouse pup under control condition, during isoproterenol (ISO) application and wash (upper panel), I-V relationship (middle panel), and normalized current plots (lower panel). (B) Example traces of whole-cell currents in a P17 mouse under control condition, during isoproterenol (ISO) application and wash (upper panel), $I-V$ relationship (middle panel), and normalized current plots (lower panel). (C) Example traces of whole-cell currents in a P9 mouse pup under control condition during nifedipine (NIF) and NIF + ISO applications (upper panel), I-V relationship (middle panel), and normalized current plots (lower panel). (D) Example traces of whole-cell currents in a P8 mouse pup under control condition during nifedipine (NIF) and NIF + ISO applications (upper panel), I-V relationship (middle panel), and normalized current plots (lower panel). $\left(^{*}\right) P<0.05$. Scale bars: $25 \mathrm{msec}$ and $500 \mathrm{pA}$.

pocampus and visual cortex (Mintz et al. 1992). Their roles in plasticity and learning are proposed to be bridging neuronal excitation to transcription of $\mathrm{Ca}^{2+}$-regulated genes (Bading et al. 1993; Impey et al. 1996; Deisseroth et al. 1998; Dolmetsch et al. 2001). In the hippocampus, LTCCs mediate protein synthesis sensitive, NMDAR-independent late phase LTP and spatial learning (Grover and Teyler 1990; Moosmang et al. 2005). However, in the aPC, we have shown that LTCC activation is dependent on NMDAR activation and both channels play critical but distinct roles in the early odor preference learning (Mukherjee and Yuan 2016). Here either D-APV or nifedipine blocked isoproterenol induced learning (Fig. $3 \mathrm{~A}$ ), consistent with the learning requirement on both NMDARs and LTCCs. Between the two isotypes CaV1.2 and CaV1.3, CaV1.2 has been identified as a major player since CaV1.2 knock out (Moosmang et al. 2005) but not CaV1.3 knockout (Clark et al. 2003) mice have deficiency in synaptic plasticity or learning. CaV1.2 channels contain PKA binding site (Davare et al. 2001). PKA activation by cAMP enhances LTCC current in the hippocampus (Kavalali et al. 1997; Hoogland and Saggau 2004), likely through phosphorylation of LTCCs. Our result showing PKA-dependent enhancement of calcium currents by $\beta$-adrenoceptors in neonatal aPC is consistent with these reports.

An intriguing result from this study 3A. Direct activation of $\beta$-adrenoceptors in the aPC induced odor preference learning when paired with odor alone. One-way ANOVA demonstrated significant group effects $\left(F_{(4,22)}=11.82\right.$, $P<0.01$, Fig. 3A). Post hoc Fisher Test showed that the isoproterenol-infused group spent significantly more time in peppermint $(65.6 \% \pm 1 \%, n=6)$ compared with the saline infused group $(37.2 \% \pm 2.6 \%, n=6, t=5.50, P<0.01)$. The isoproterenol effect was reversed by co-infusion of $\mathrm{H} 89(43.9 \% \pm 2.6 \%, n=6, t=4.21$, $P<0.01)$. Coinfusion of nifedipine prevented early odor preference learning $(39.3 \pm 3.21, n=5, t=7.8, P<0.01)$. These results suggest that LTCC-mediated calcium signaling is critical. $\beta$-Adrenoceptor augmentation of the LTCC currents likely promotes LTCC-mediated plasticity and learning through cAMP/ PKA signaling (proposed pathways and interactions shown in Fig. 3B). $\beta$-Adrenoceptor-dependent LTCC activation at olfactory bulb synapses is also critical for odor associative learning (Zhang et al. 2010; Jerome et al. 2012). One caveat is that in vivo drug infusion affects more cell types than pyramidal cells in the aPC.

Detailed characterizations of whole-cell calcium currents in the piriform cortex have revealed diverse kinetics of the calcium currents among pyramidal cells (Magistretti et al. 1999; Suzuki and Bekkers 2006), similar to what we have observed in this study. These studies demonstrate various calcium channels in piriform cortex neurons including at least L-, $\mathrm{N}$-, and T-type channels recorded at the soma. In this study, we focused on the nifedipinesensitive LTCCs and its regulation by $\beta$-adrenoceptor activations given their roles in odor learning. LTCCs contribute to $\sim 50 \%$ of the total voltage-gated $\mathrm{Ca}^{2+}$ current in pyramidal cells in the hip- is the age-dependent changes of both LTCC component and $\beta$-adrenoceptor modulation. LTCC component in the aPC pyramidal cell is larger $(\sim 50 \%)$ in the sensitive period mice $(\mathrm{P} 7-10)$
A

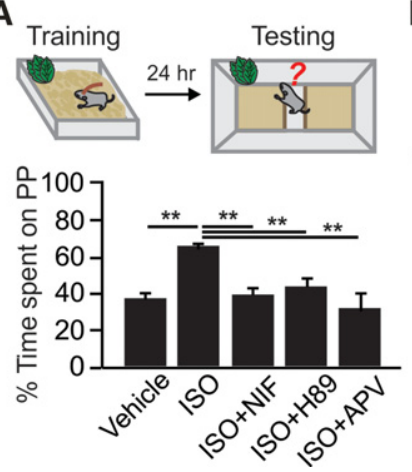

B

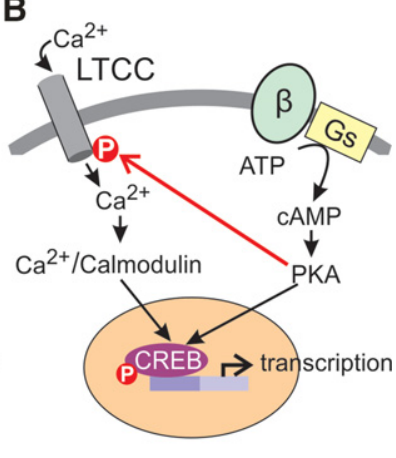

Figure 3. The interaction of $\beta$-adrenoceptors and LTCCs in early odor peppermint-scented bedding in vehicle, ISO or NIF + ISO infused groups. (**) $P<0.01$. (B) A proposed model for $\beta$-adrenoceptor interaction with LTCCs in anterior piriform cortex of pyramidal neurons. $\beta$-adrenoceptor activation serves as unconditioned stimulus to activate CAMP/PKA pathway. PKA translocates to the nucleus to phosphorylate CREB, and phosphorylate LTCCs in the membrane to enhance LTCC-mediated calcium signaling, which converges with CAMP/PKA pathway on CREB phosphorylation. preference learning in mice. $(A)$ Percentage of time spent over 
compared with those beyond the sensitive period ( 27\%, P1420). A reduced proportion of LTCC currents parallel agedependent down-regulation of NMDARs (Franks and Isaacson 2005) that has been attributed to reduced plasticity in older rats in the aPC (Poo and Isaacson 2011). Altered adrenoceptor expressions and functions with age can also contribute to changes in plasticity (Pandipati and Schoppa 2012; Ghosh et al. 2015). For example, we have shown previously that $\beta$-adrenoceptor activation enhances excitatory inputs and reduces inhibitory inputs in the aPC only in mice within the sensitive period (Ghosh et al. 2015). Here we provide further evidence for postsynaptic correlates of $\beta$-adrenoceptor roles in synaptic plasticity and odor learning through LTCCs. The lack of modulation of LTCCs by $\beta$-adrenoceptors in older mice may relate to reduced expression of either LTCCs or $\beta$-adrenoceptors with age.

\section{Acknowledgments}

We thank Ms. Rachel Atkinson for editing the manuscript. This work was supported by the Natural Sciences and Engineering Research Council of Canada (NSERC) discovery grants to Q.Y. (\#418451-2013) and X.C. (\#261384-2008).

\section{References}

Bading H, Ginty DD, Greenberg ME. 1993. Regulation of gene expression in hippocampal neurons by distinct calcium signaling pathways. Science 260: $181-186$.

Clark NC, Nagano N, Kuenzi FM, Jarolimek W, Huber I, Walter D, Wietzorrek G, Boyce S, Kullmann DM, Striessnig J, et al. 2003 Neurological phenotype and synaptic function in mice lacking the $\mathrm{CaV} 1.3 \alpha$ subunit of neuronal L-type voltage-dependent $\mathrm{Ca}^{2+}$ channels. Neuroscience 120: 435-442.

Davare MA, Avdonin V, Hall DD, Peden EM, Burette A, Weinberg RJ, Horne MC, Hoshi T, Hell JW. 2001. A $\beta 2$ adrenergic receptor signaling complex assembled with the $\mathrm{Ca}^{2+}$ channel Cav1.2. Science 293: 98-101.

Davis SE, Bauer EP. 2012. L-type voltage-gated calcium channels in the basolateral amygdala are necessary for fear extinction. J Neurosci 32: 13582-13586.

Deisseroth K, Heist EK, Tsien RW. 1998. Translocation of calmodulin to the nucleus supports CREB phosphorylation in hippocampal neurons. Nature 392: 198-202.

Dolmetsch RE, Pajvani U, Fife K, Spotts JM, Greenberg ME. 2001. Signaling to the nucleus by an L-type calcium channel-calmodulin complex through the MAP kinase pathway. Science 294: 333-339.

Franks KM, Isaacson JS. 2005. Synapse-specific downregulation of NMDA receptors by early experience: a critical period for plasticity of sensory input to olfactory cortex. Neuron 47: 101-114.

Ghosh A, Purchase NC, Chen X, Yuan Q. 2015. Norepinephrine modulates pyramidal cell synaptic properties in the anterior piriform cortex of mice: age-dependent effects of $\beta$-adrenoceptors. Front Cell Neurosci 9: 450.

Gray R, Johnston D. 1987. Noradrenaline and $\beta$-adrenoceptor agonists increase activity of voltage-dependent calcium channels in hippocampal neurons. Nature 327: 620-622.

Grimes MT, Harley CW, Darby-King A, McLean JH. 2012. PKA increases in the olfactory bulb act as unconditioned stimuli and provide evidence for parallel memory systems: pairing odor with increased PKA creates intermediate- and long-term, but not short-term, memories. Learn Mem 19: $107-115$

Grover LM, Teyler TJ. 1990. Two components of long-term potentiation induced by different patterns of afferent activation. Nature 347: 477-479.

Hell JW, Westenbroek RE, Warner C, Ahlijanian MK, Prystay W, Gilbert MM, Snutch TP, Catterall WA. 1993. Identification and differential subcellular localization of the neuronal class C and class D L-type calcium channel $\alpha 1$ subunits. J Cell Biol 123: 949-962.

Hess P, Lansman JB, Nilius B, Tsien RW. 1986. Calcium channel types in cardiac myocytes: modulation by dihydropyridines and $\beta$-adrenergic stimulation. J Cardiovasc Pharmacol 8(Suppl 9): S11-S21.
Hoogland TM, Saggau P. 2004. Facilitation of L-type $\mathrm{Ca}^{2+}$ channels in dendritic spines by activation of $\beta 2$ adrenergic receptors. J Neurosci 24: $8416-8427$.

Impey S, Mark M, Villacres EC, Poser S, Chavkin C, Storm DR. 1996. Induction of CRE-mediated gene expression by stimuli that generate long-lasting LTP in area CA1 of the hippocampus. Neuron 16: 973-982.

Jerome D, Hou Q Yuan Q. 2012. Interaction of NMDA receptors and L-type calcium channels during early odor preference learning in rats. Eur $J$ Neurosci 36: 3134-3141.

Kapur A, Yeckel MF, Gray R, Johnston D. 1998. L-Type calcium channels are required for one form of hippocampal mossy fiber LTP. J Neurophysiol 79: $2181-2190$.

Kavalali ET, Hwang KS, Plummer MR. 1997. cAMP-dependent enhancement of dihydropyridine-sensitive calcium channel availability in hippocampal neurons. J Neurosci 17: 5334-5348.

Lashgari R, Motamedi F, Zahedi Asl S, Shahidi S, Komaki A. 2006. Behavioral and electrophysiological studies of chronic oral administration of L-type calcium channel blocker verapamil on learning and memory in rats. Behav Brain Res 171: 324-328.

Lethbridge R, Hou Q, Harley CW, Yuan Q. 2012. Olfactory bulb glomerular NMDA receptors mediate olfactory nerve potentiation and odor preference learning in the neonate rat. PLoS One 7: e35024.

Magistretti J, Brevi S, de Curtis M. 1999. Biophysical and pharmacological diversity of high-voltage-activated calcium currents in layer II neurones of guinea-pig piriform cortex. J Physiol 518(Pt 3): 705-720.

McLean JH, Harley CW, Darby-King A, Yuan Q. 1999. pCREB in the neonate rat olfactory bulb is selectively and transiently increased by odor preference-conditioned training. Learn Mem 6: 608-618.

Mintz IM, Adams ME, Bean BP. 1992. P-type calcium channels in rat central and peripheral neurons. Neuron 9: 85-95.

Moosmang S, Haider N, Klugbauer N, Adelsberger H, Langwieser N, Muller J, Stiess M, Marais E, Schulla V, Lacinova L, et al. 2005. Role of hippocampal Cav1.2 $\mathrm{Ca}^{2+}$ channels in NMDA receptor-independent synaptic plasticity and spatial memory. J Neurosci 25: 9883-9892.

Morrison GL, Fontaine CJ, Harley CW, Yuan Q. 2013. A role for the anterior piriform cortex in early odor preference learning: evidence for multiple olfactory learning structures in the rat pup. J Neurophysiol 110: $141-152$.

Mukherjee B, Yuan Q. 2016. NMDA receptors in mouse anterior piriform cortex initialize early odor preference learning and L-type calcium channels engage for long-term memory. Sci Rep. 6: 35256.

Nakamura S, Kimura F, Sakaguchi T. 1987. Postnatal development of electrical activity in the locus ceruleus. J Neurophysiol 58: 510-524.

Pandipati S, Schoppa NE. 2012. Age-dependent adrenergic actions in the main olfactory bulb that could underlie an olfactory-sensitive period. $J$ Neurophysiol 108: 1999-2007.

Poo C, Isaacson JS. 2011. A major role for intracortical circuits in the strength and tuning of odor-evoked excitation in olfactory cortex. Neuron 72: 41-48.

Reuter H. 1983. Calcium channel modulation by neurotransmitters, enzymes and drugs. Nature 301: $569-574$.

Sullivan RM, Landers M, Yeaman B, Wilson DA. 2000. Good memories of bad events in infancy. Nature 407: 38-39.

Suzuki N, Bekkers JM. 2006. Neural coding by two classes of principal cells in the mouse piriform cortex. J Neurosci 26: 11938-11947.

Suzuki N, Bekkers JM. 2011. Two layers of synaptic processing by principal neurons in piriform cortex. J Neurosci 31: 2156-2166.

Weisskopf MG, Bauer EP, LeDoux JE. 1999. L-type voltage-gated calcium channels mediate NMDA-independent associative long-term potentiation at thalamic input synapses to the amygdala. J Neurosci 19: 10512-10519.

Yuan Q, Harley CW, McLean JH. 2003. Mitral cell $\beta 1$ and 5-HT2A receptor colocalization and cAMP coregulation: a new model of norepinephrine-induced learning in the olfactory bulb. Learn Mem 10: $5-15$.

Yuan Q, Shakhawat AM, Harley CW. 2014. Mechanisms underlying early odor preference learning in rats. Prog Brain Res 208: 115-156.

Yue DT, Herzig S, Marban E. 1990. $\beta$-adrenergic stimulation of calcium channels occurs by potentiation of high-activity gating modes. Proc Natl Acad Sci 87: 753-757.

Zhang JJ, Okutani F, Huang GZ, Taniguchi M, Murata Y, Kaba H. 2010. Common properties between synaptic plasticity in the main olfactory bulb and olfactory learning in young rats. Neuroscience 170: 259-267.

Received December 9, 2016; accepted in revised form January 3, 2017. 


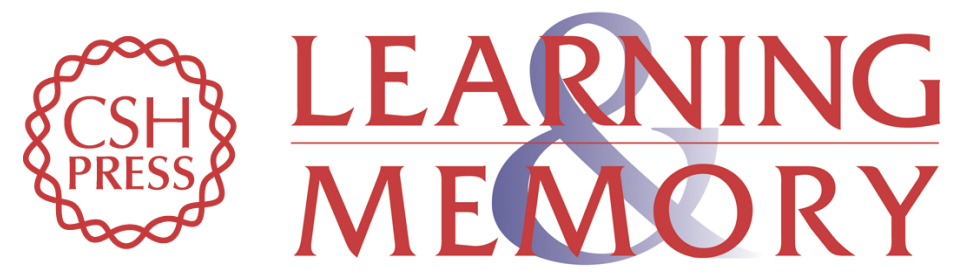

\section{$\beta$-Adrenoceptor activation enhances L-type calcium channel currents in anterior piriform cortex pyramidal cells of neonatal mice: implication for odor learning}

Abhinaba Ghosh, Bandhan Mukherjee, Xihua Chen, et al.

Learn. Mem. 2017, 24:

Access the most recent version at doi:10.1101//m.044818.116

References This article cites 38 articles, 15 of which can be accessed free at: http://learnmem.cshlp.org/content/24/3/132.full.html\#ref-list-1

Creative This article is distributed exclusively by Cold Spring Harbor Laboratory Press for the Commons first 12 months after the full-issue publication date (see

License http://learnmem.cshlp.org/site/misc/terms.xhtml). After 12 months, it is available under a Creative Commons License (Attribution-NonCommercial 4.0 International), as described at http://creativecommons.org/licenses/by-nc/4.0/.

Email Alerting Receive free email alerts when new articles cite this article - sign up in the box at the Service top right corner of the article or click here. 